\title{
Distribution patterns of ferns and lycophytes in the Coastal Region of the state of Rio Grande do Sul, Brazil
}

\author{
Felipe Gonzatti ${ }^{*}$, Letícia Machado ${ }^{2}$ and Paulo Günter Windisch²
}

Received: February 22, 2016

Accepted: March 21, 2016

\begin{abstract}
A survey of ferns and lycophytes of the Coastal Region of the state of Rio Grande do Sul (CRRS) was performed based on field work and collections of the main regional herbaria. The following were evaluated for each species: preferential habits (terrestrial, epiphytic or aquatic), geographic distribution patterns and habitats (forest, grassland, and wetland). The occurrence of a latitudinal gradient in diversity was tested over five latitudinal ranges using the Sørensen Similarity Index. A total of 17 lycophyte and 206 fern species representing 28 families was found between the latitudes of $29^{\circ}$ and $34^{\circ}$ S. Exclusively terrestrial species were predominant (162), with the majority (113) exhibiting wide Neotropical distributions, followed by species that also occurred in the state of Paraná (44). The forest habitat harbored the greatest number of species (159), while grasslands had the fewest (26). Cluster analysis showed pronounced floristic differentiation among latitudinal Ranges III $\left(31^{\circ} 01^{\prime}\right.$ to $\left.32^{\circ} \mathrm{S}\right)$ and IV $\left(32^{\circ} 01^{\prime}\right.$ to $\left.31^{\circ} \mathrm{S}\right)$, with a similarity index of only 0.41 . Our results demonstrate a strong north-to-south reduction in species richness in the study area, which is related to environmental conditions along the latitudinal gradient and, especially, microclimatic differences in the transition zone between the Atlantic Forest and Pampa biomes.
\end{abstract}

Keywords: coastal vegetation, ecology, floristic diversity, latitudinal gradient, phytogeography

\section{Introduction}

Ferns and lycophytes are significant components of tropical and temperate floras, occupying a variety of ecological niches (Holttum 1938; Tryon \& Tryon 1982; Windisch 1992; 1996; 2002; Page 2002; Sharpe et al. 2010), and having patterns of geographical distribution that are associated with the long distance dispersal capacity of their spores (Tryon 1970; Smith 1972; Barrington 1993; Wolf et al. 2001).

In the meridional portion of South America (the "Southern Cone"), centers of species diversity and endemism, as well as limits to floristic distributions, have been related to paleogeographical alterations that produced climatic barriers and interrupted floristic continuity (Sota 1973; Ponce et al. 2002). At a local scale, climatic factors, such as temperature and humidity (Kessler 2001; Kessler et al. 2011), variation in the chemical composition of the edaphic matrix (Tuomisto \& Ruokolainen 1993; Tuomisto \& Poulsen 1996; Tuomisto et al. 2003a; Tuomisto et al. 2003b; Tuomisto et al. 2014), variation in $\mathrm{pH}$ (Ranal 1995a), environmental heterogeneity (Sylvestre \& Windisch 2003; Dittrich et al. 2005; Nettesheim et al. 2014), and fragmentation and edge effect (Paciencia \& Prado 2005) have been implicated in determining fern and lycophyte distribution.

\footnotetext{
${ }^{1}$ Herbário da Universidade de Caxias do Sul, Universidade de Caxias do Sul, Rua Francisco Getúlio Vargas 1130, 95020-972, Caxias do Sul, RS, Brazil ${ }^{2}$ Programa de Pós-graduação em Botânica, Universidade Federal do Rio Grande do Sul, Av. Bento Gonçalves, 9500, 91501-970, Porto Alegre, RS,

*Corresponding author: fgonzatti@ucs.br
} 
There are about 140 lycophyte and 1,100 fern species in Brazil (Prado \& Sylvestre 2015), with the greatest number occurring in the montane regions of the Atlantic Forest biome (Windisch 2002; Dittrich et al. 2005; Prado \& Labiak 2009). The presence of a center of diversity and endemism of ferns and lycophytes in the Atlantic Forest of southeastern Brazil (Tryon 1972), is relevant for the diversity of southern Brazil, including the Coastal Region of the state of Rio Grande do Sul. This diversity within Rio Grande do Sul is represented by approximately 397 species (Sehnem 1977), mainly known from regional surveys (Mondin \& Silveira 1989; Bueno \& Senna 1992; Senna \& Waechter 1997; Athayde-Filho \& Windisch 2006; Schmitt et al. 2006; Lehn et al. 2009; Santos \& Windisch 2008 Schmitt \& Goetz 2010; Becker et al. 2013; Silva et al. 2013; Gonzatti et al. 2014a; Gonzatti et al. 2014b; Mallmann \& Schmitt 2014), phytogeographic and palynological reviews (Sehnem 1977; Lorscheitter et al. 1998; 1999; 2001; 2002; 2005; 2009), and research on ecology, phenology and development (Schmitt \& Windisch 2010; Schneider \& Schmitt 2011; Schmitt \& Windisch 2012; Rocha et al. 2013; Neumann et al. 2014; Quevedo et al. 2014; among others).

The Coastal Region possesses distinct phases of vegetational succession, featuring a mosaic of floristic communities from open grassland and wet areas to arboreal communities (Waechter 1990; Waechter \& Jarenkow 1998; Müller \& Waechter 2001). This mosaic is determined mainly by edaphic conditions, but also by wind action and extreme insolation (Rambo 1956). However, there is general transition in vegetation cover from it being scarce and sparse at the coastline, to gradually giving rise to forests with tropical characteristics in the continental interior (Rambo 1951; 1954; Klein 1984; Waechter 1990).

A marked change in vegetation cover is mainly determined by climatic changes close to the $30^{\circ} \mathrm{S}$ parallel, where abrupt differences in rainfall and temperature regimes occur, resulting in a north-to-south reduction of species richness, especially with regard to tropical elements (Rambo 1951; Waechter 1990). This north-to-south change from a tropical to a temperate climate induces floristic changes including the substitution of the Atlantic Forest biome by the Pampa biome in this portion of Rio Grande do Sul (Waechter 1985; Fiaschi \& Pirani 2009; Overbeck et al. 2012).

Considering that only about $15 \%$ of the original Coastal Region vegetation coverage remains (Cordeiro \& Hasenack 2012), and that area is a priority for conservation for the state of Rio Grande do Sul (MMA 2000), an increase in the knowledge of flora in this transitional vegetation formation would be valuable. Through this inventory, we seek to understand the distribution patterns of ferns and lycophytes among different vegetation physiognomies and along a latitudinal gradient in the study area, and the relationships of these plants with adjacent plant communities.

\section{Materials and methods}

\section{Study area}

The study area comprises the entire Coastal Region of the state of Rio Grande do Sul (CRRS hereafter), situated between the latitudes of $29^{\circ} 17^{\prime} \mathrm{S}$ to $33^{\circ} 41^{\prime} \mathrm{S}$ and the longitudes of $49^{\circ} 43^{\prime} \mathrm{W}$ to $53^{\circ} 31^{\prime} \mathrm{W}$. The area encompasses about $33,000 \mathrm{~km}^{2}$, and is characterized by extensive lowlands and several shallow freshwater lakes (Fig. 1), extending from the municipality of Torres in the north, to Chuí in the south. The CRRS is limited to the west, continental, side by the geomorphological formations of the "Sulriograndense" Plateau (a.k.a. "Serra Geral"), to the north, by the Central Depression and by the Sulriograndense Shield to the south. The origin of the Coastal Region is discussed by Tomazelli et al. (2000), Villwock \& Tomazelli (2007) and Buchmann et al. (2009).

Despite the relative uniformity of these coastal areas, microtopographic variation allows for two main soil types: well drained sandy soils at low elevations, and poorly drained sandy, clayish or peaty soils in the lowlands. Most of the terrain is covered by Solodic Planosol derived from alluvial and lacustrine depositions or sandstone decomposition. These Planosol areas are poorly drained and have low fertility, with forest growing on peat. The northern portion is characterized by Hydromorphic Humic Quartz-Soil type (Neosol) of sedimentary origin formed during the Holocene and featuring a high accumulated-carbon content and poor drainage. Also in the northern portion, shallow and highly fertile Chernosols are present, with rock mixtures in the A horizon. Red Latosol can also be found, constituting deep soils, rich in iron and nutrient poor in the A horizon. Dune banks of depositional origin prevail along the coastline, composed of quartz sands of low pedogenetic structuration, low fertility and high wind mobility (Moser 1990; Embrapa 2006).

According to the Köppen classification, the climate is Cfa type, subtropical with hot summers with the coldest monthly mean temperature higher than $-3{ }^{\circ} \mathrm{C}$ and the warmest above $22^{\circ} \mathrm{C}$, with an annual average of around $17.6^{\circ} \mathrm{C}$. Monthly precipitation varies between 100 and 170 $\mathrm{mm}$, heterogeneously distributed between the extreme north and south of the Coastal Region (annual average: 1,423 $\mathrm{mm}$ in Torres and 1,186 and in Santa Vitória do Palmar). These climate conditions occur in most regions with altitudes below 600-650 m alt., and cover all the Coastal Region, reaching the limit at the $\mathrm{Cfb}$ climate type being found at the highest elevations (Moreno 1961; Alvares et al. 2013).

\section{Sampling and data processing}

Field work was conducted between March 2013 and 
December 2014 in 19 municipalities (Fig. 1). Spot inventories were conducted in different vegetation formations with random sampling following the procedure described by Filgueiras et al. (1994), from the seaside and up to $50 \mathrm{~m}$ alt. in regions with slope. The samples were collected and preserved following Windisch (1992). Voucher specimens were deposited in the ICN and HUCS herbaria (acronyms based on Thiers 2015).

Collections of the following herbaria were reviewed: Herbário do Instituto de Ciências Naturais, Universidade Federal do Rio Grande do Sul (ICN), Instituto Anchietano de Pesquisas, Universidade do Vale do Rio dos Sinos (PACA), Herbário Alarich Schultz, Fundação Zoobotânica do RS (HAS), Herbário da Universidade de Caxias do Sul (HUCS), Herbário da Universidade Federal de Pelotas (PEL) and Herbário da Universidade Federal de Rio Grande (HURG). All exsiccates from the study area were annotated with updated identifications and nomenclature, and their location and habitat information were added to our database.

The taxonomic delimitation of families and genera follows Smith et al. (2008), with the genus Deparia Hook. \& Grev. belonging in Athyriaceae (Rothfels et al. 2012). Adaptations to Lycopodiaceae followed Øllgaard (2012). For the genus Blechnum L. we followed Perrie et al. (2014). For Tryonia J. Prado, A. T. Cochran we followed Cochran et al. (2014), and for Mickelia R. C. Moran et al. we followed Moran et al. (2010). Abbreviations of the names of the authors of species follow the Species List of the Flora of Brazil (Prado \& Sylvestre 2015).

Species habits were categorized as terrestrial, epiphytic or aquatic and assigned to habitats: forest, grassland, wetland or combinations thereof. Species distribution patterns were categorized based on Waechter (2002) and Cabrera \& Willink (1980), as follows:

Global distribution:

Cosmopolitan: widely distributed across the five continents;

Amphipacific: disjunct distribution in the tropical and subtropical regions of America and Asia;

Holarctic: wide distribution in the temperate regions of the Northern Hemisphere and Eurasian region;

Pantropical: distribution in the American, African and Asian tropical regions;

Neotropical: distribution restricted to the American tropical and subtropical region;

Neotropical distribution:

Neotropical-Antarctic: distribution in the Neotropical region, with eventual occurrence in temperate SouthAmerican regions;

Neotropical-Atlantic: restricted to the Atlantic province;

Neotropical-Paranaense: restricted to the Paranaense province;

Neotropical-Pampeana: restricted to the Pampa biome.

The latitudinal distributions of the taxa within the study area were verified by their presence or absence in five latitudinal ranges, according to Waechter (1998). In this study, Ranges I and V were smaller than Ranges II, III and IV, as only areas within the state of Rio Grande do Sul were evaluated, and did not extend into the state of Santa Catarina or Uruguay (Fig. 1).

Range I (extreme North): species occurring from $29^{\circ} 17^{\prime}$ south to $30^{\circ} \mathrm{S}$;

Range II (North): species occurring between the parallels $30^{\circ} 01^{\prime}$ and $31^{\circ} \mathrm{S}$

Range III (Middle center): species occurring between the parallels $31^{\circ} 01^{\prime}$ and $32^{\circ} \mathrm{S}$;

Range IV (South): species occurring between the parallels $32^{\circ} 01^{\prime}$ and $33^{\circ} \mathrm{S}$;

Range V (extreme South): species occurring beside the parallel $33^{\circ} 01^{\prime}$ and $33^{\circ} 41^{\prime}$ 's.

The floristic similarity among distinct latitudinal ranges was evaluated by applying the Sørensen Similarity Index using the Unweighted Pair-Group Method with Arithmetic Logarithm (UPGMA). This analysis was processed by the Past 3.04 software (Hammer et al. 2001).

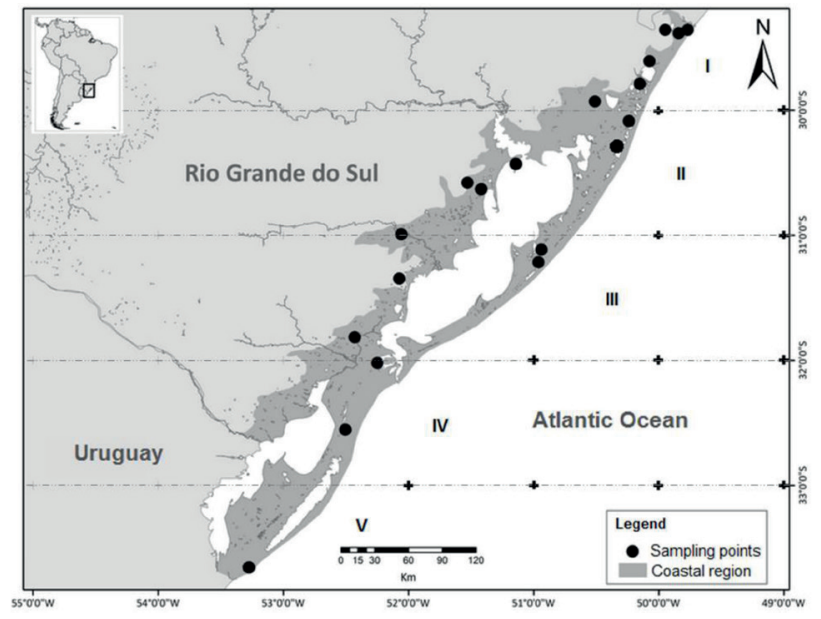

Figure 1. Location of the Coastal Region of Rio Grande do Sul, highlighting the sampled localities and the five latitudinal ranges (I: $29^{\circ} 17^{\prime}-30^{\circ} \mathrm{S}$, II: $30^{\circ} 01^{\prime}-31^{\circ}$, III: $31^{\circ} 01^{\prime}-32^{\circ} \mathrm{S}$, IV: $32^{\circ} 01^{\prime}-33^{\circ} \mathrm{S}$, V: $\left.33^{\circ} 01^{\prime}-33^{\circ} 41^{\prime} S\right)$.

\section{Results}

A total of 3,450 herbarium records were evaluated, including 520 collected during our field work and 2,930 previously existing in collections. In total the records represented 223 species in 79 genera and 28 families, of which 17 were species of lycophytes and 206 were species of ferns (Tab. 1).

The largest values for species richness were for the families: Pteridaceae (34), Polypodiaceae (29), Thelypteridaceae (23), Dryopteridaceae (22), Aspleniaceae (18) and Blechnaceae (13). Marattiaceae, Psilotaceae, Lygodiaceae, Isoetaceae and Equisetaceae had one species each (Tab. 1). The genera with 
Table 1. Floristic composition found in the Coastal Region of Rio Grande do Sul. Families, Species, Habit: T - terrestrial; E - epiphyte; A - aquatic. Vegetation: F - forest; G - grassland; W - wet land. Geographic distribution pattern: COS - cosmopolitan; PAN - pantropical; HOL - holarctic; ANP - anfipacific; NEO -neotropical; NEO-ATL - neotropical-atlantic; NEO-PAR - neotropical-paranaense; NEO-PAM

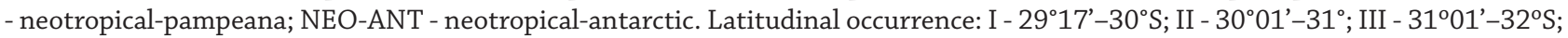
IV $-32^{\circ} 01^{\prime}-33^{\circ} \mathrm{S} ; \mathrm{V}-33^{\circ} 01^{\prime}-33^{\circ} 41^{\prime}$ of South latitude. Herbarium voucher: reference material deposited in the herbaria ICN, HAS, PACA, HUCS e HURG.

\begin{tabular}{|c|c|c|c|c|c|}
\hline Families/Species & Habit & Habitat & Geographic pattern & Latitudinal occurrence & Herbarium voucher \\
\hline \multicolumn{6}{|l|}{ ANEMIACEAE } \\
\hline Anemia ferruginea Humb. \& Bonpl. ex Kunth & $\mathrm{T}$ & $\mathrm{F}$ & NEO & I & PACA 100902 \\
\hline Anemia phyllitidis (L.) Sw. & $\mathrm{T}$ & $\mathrm{F}$ & NEO & I, II, III, IV & HUCS 41492 \\
\hline Anemia tomentosa (Sav.) Sw. & $\mathrm{T}$ & $\mathrm{G} / \mathrm{F}$ & NEO & I, II, III, V & HUCS 41507 \\
\hline Anemia warmingii Prantl & $\mathrm{T}$ & $\mathrm{F}$ & NEO-ATL & I & ICN 107595 \\
\hline \multicolumn{6}{|l|}{ ASPLENIACEAE } \\
\hline Asplenium abscissum Willd. & $\mathrm{T}$ & $\mathrm{F}$ & NEO & I, III & ICN 171238 \\
\hline Asplenium bradei Rosenst. & $\mathrm{T}$ & $\mathrm{F}$ & NEO-ATL & I, II & HUCS 41361 \\
\hline Asplenium brasiliense Sw. & $\mathrm{T}$ & F & NEO-PAR & I, II & ICN 161392 \\
\hline Asplenium claussenii Hieron. & $\mathrm{T}$ & $\mathrm{F}$ & NEO & I, II, III, IV & ICN 176197 \\
\hline Asplenium gastonis Fée & $\mathrm{T} / \mathrm{E}$ & $\mathrm{F}$ & NEO-PAR & I, II, III, IV & HUCS 41374 \\
\hline Asplenium harpeodes Kunze & $\mathrm{T}$ & $\mathrm{F}$ & NEO & I, II & ICN 171237 \\
\hline Asplenium incurvatum Fée & $\mathrm{E}$ & $\mathrm{F}$ & NEO-ATL & I, II & PACA 72760 \\
\hline Asplenium kunzeanum Klotzsch ex Rosenst. & $\mathrm{T}$ & $\mathrm{F}$ & NEO-ATL & I & ICN 176481 \\
\hline Asplenium martianum C. Chr. & $\mathrm{T}$ & F & NEO-ATL & I & ICN 176746 \\
\hline Asplenium mucronatum C.Presl & $\mathrm{E}$ & $\mathrm{F}$ & NEO-PAR & I & HUCS 40582 \\
\hline Asplenium oligophyllum Kaulf. & $\mathrm{T}$ & $\mathrm{F}$ & NEO & I & ICN 171106 \\
\hline Asplenium scandicinum Kaulf. & E & $\mathrm{F}$ & NEO-PAR & I, II, III & HUCS 39487 \\
\hline Asplenium sellowianum (Hieron.) Hieron. & $\mathrm{T}$ & $\mathrm{F}$ & NEO-PAR & I, II, III, IV, V & HUCS 41134 \\
\hline Asplenium serra Langsd. \& Fisch. & $\mathrm{T}$ & $\mathrm{F}$ & NEO & I, II, III & ICN 161365 \\
\hline Asplenium ulbrichtii Rosenst. & $\mathrm{T}$ & F & NEO-PAR & II, III, V & HUCS 41523 \\
\hline Asplenium uniseriale Raddi & $\mathrm{T}$ & $\mathrm{F}$ & NEO & I & ICN 124310 \\
\hline Hymenasplenium triquetrum (N. Murak. \& R.C. Moran) L. Regalado \& Prada & $\mathrm{T}$ & $\mathrm{F}$ & NEO & I & ICN 124318 \\
\hline \multicolumn{6}{|l|}{ ATHYRIACEAE } \\
\hline Deparia petersenii (Kunze) M. Kato & $\mathrm{T}$ & $\mathrm{F}$ & ANP & I, II, III, V & HUCS 41400 \\
\hline Diplazium herbaceum Fée & $\mathrm{T}$ & $\mathrm{F}$ & NEO-ATL & I, II & ICN 107001 \\
\hline Diplazium plantaginifolium (L.) Urb. & $\mathrm{T}$ & F & NEO & I, II & ICN 161430 \\
\hline \multicolumn{6}{|l|}{ BLECHNACEAE } \\
\hline Blechnum acutum (Desv.) Mett. & $\mathrm{T} / \mathrm{E}$ & $\mathrm{F}$ & NEO & I, II, III, IV & HUCS 41401 \\
\hline Blechnum auriculatum Cav. & $\mathrm{T}$ & $\mathrm{F}$ & NEO-PAR & I, II, III, IV, V & HUCS 41084 \\
\hline Blechnum austrobrasilianum de la Sota & $\mathrm{T}$ & $\mathrm{F}$ & NEO-PAR & I, II, III, IV & HUCS 41067 \\
\hline Blechnum brasiliense Desv. & $\mathrm{T}$ & $\mathrm{F} / \mathrm{W}$ & NEO & I, II, III, IV, V & HUCS 41069 \\
\hline Blechnum cordatum (Desv.) Hieron. & $\mathrm{T}$ & $\mathrm{G} / \mathrm{F} / \mathrm{W}$ & NEO-ANT & I, II, III, IV, V & HUCS 41055 \\
\hline Blechnum gracile Kaulf. & $\mathrm{T}$ & $\mathrm{F}$ & NEO & I & ICN 173499 \\
\hline Blechnum laevigatum Cav. & $\mathrm{T}$ & G & NEO-PAR & I, II, III & ICN 170402 \\
\hline Blechnum lehmannii Hieron. & $\mathrm{T}$ & $\mathrm{F}$ & NEO & I & ICN 114698 \\
\hline Blechnum occidentale L. & $\mathrm{T}$ & $\mathrm{F}$ & NEO & I, II, III, IV & ICN 176486 \\
\hline Blechnum polypodioides Raddi & $\mathrm{T}$ & G & NEO & I, II, III & HUCS 38878 \\
\hline Blechnum schomburgkii (Klotzsch) C. Chr. & $\mathrm{T}$ & $\mathrm{G} / \mathrm{W}$ & NEO & I, II, III & HUCS 37970 \\
\hline Blechnum spannagelii Rosenst. & $\mathrm{T}$ & W & NEO-ATL & I, II & ICN 172982 \\
\hline Telmatoblechnum serrulatum (Rich.) Perrie, D.J. Ohlsen \& Brownsey & $\mathrm{T}$ & $\mathrm{G} / \mathrm{F} / \mathrm{W}$ & NEO & I, II, III, IV, V & HUCS 37962 \\
\hline \multicolumn{6}{|l|}{ CYATHEACEAE } \\
\hline Alsophila setosa Kaulf. & $\mathrm{T}$ & $\mathrm{F}$ & NEO-PAR & I, II, III & ICN 176724 \\
\hline Cyathea atrovirens (Langsd. \& Fisch.) Domin & $\mathrm{T}$ & $\mathrm{F}$ & NEO-PAR & I, II, III, IV & ICN 176726 \\
\hline Cyathea corcovadensis (Raddi) Domin & $\mathrm{T}$ & $\mathrm{F}$ & NEO-ATL & I & HUCS 41403 \\
\hline Cyathea delgadii Sternb. & $\mathrm{T}$ & F & NEO & I, II & HUCS 39883 \\
\hline Cyathea phalerata Mart. & $\mathrm{T}$ & $\mathrm{F}$ & NEO-ATL & I & ICN 176725 \\
\hline
\end{tabular}


Table 1. Cont.

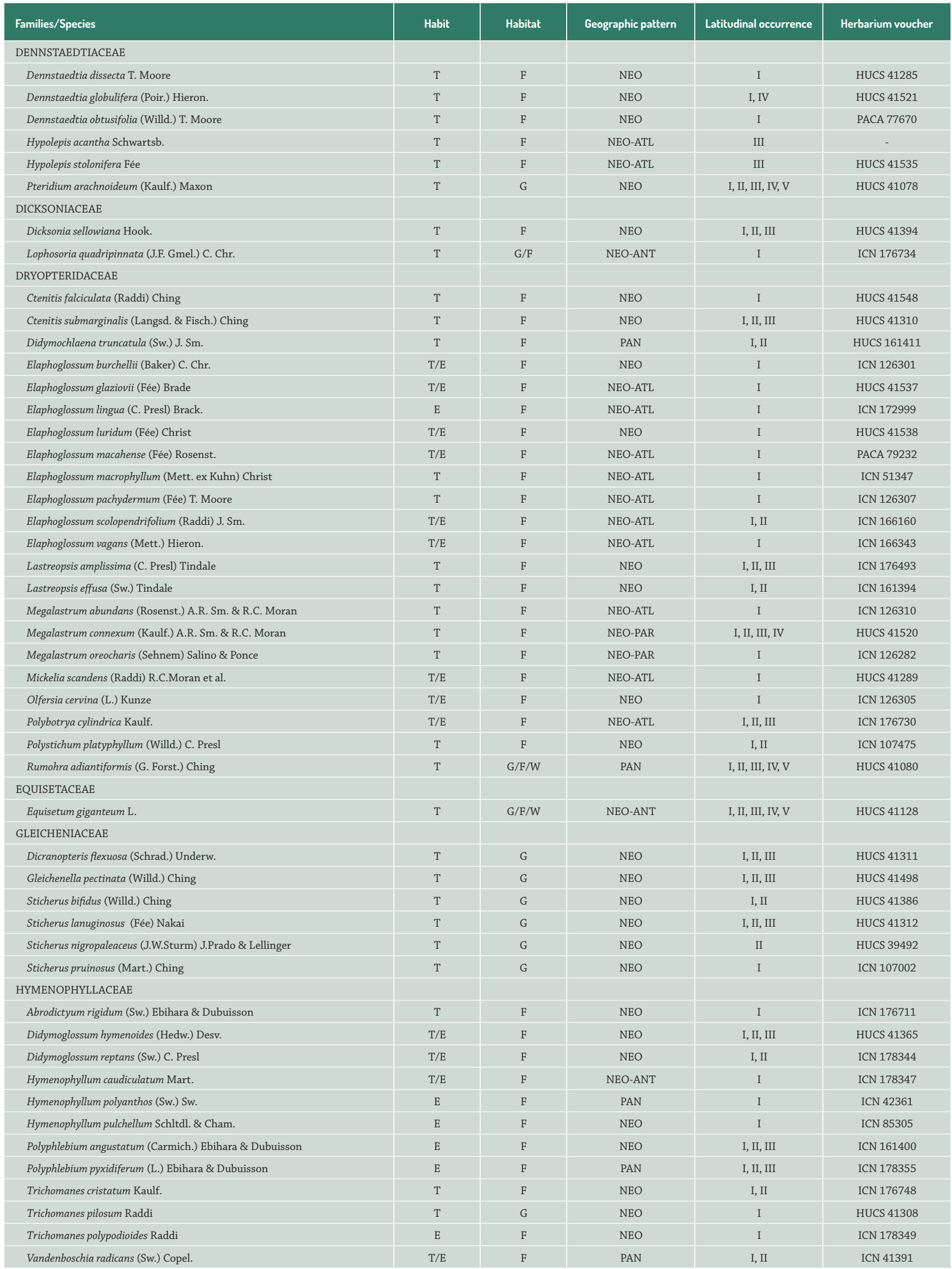


Felipe Gonzatti, Letícia Machado and Paulo Günter Windisch

Table 1. Cont.

\begin{tabular}{|c|c|c|c|c|c|}
\hline Families/Species & Habit & Habitat & Geographic pattern & Latitudinal occurrence & Herbarium voucher \\
\hline Vandenboschia rupestris (Raddi) Ebihara \& K.Iwats. & $\mathrm{T} / \mathrm{E}$ & $\mathrm{F}$ & NEO & I & ICN 178356 \\
\hline \multicolumn{6}{|l|}{ ISOETACEAE } \\
\hline Isoetes weberi Herter & $\mathrm{T}$ & W & NEO-ATL & II & PACA 98839 \\
\hline \multicolumn{6}{|l|}{ LINDSAEACEAE } \\
\hline Lindsaea lancea (L.) Bedd. & $\mathrm{T}$ & $\mathrm{F}$ & NEO & I, II & ICN 166179 \\
\hline \multicolumn{6}{|l|}{ LOMARIOPSIDACEAE } \\
\hline Lomariopsis marginata (Schrad.) Kuhn & $\mathrm{T} / \mathrm{E}$ & $\mathrm{F}$ & NEO-ATL & I & ICN 146209 \\
\hline Nephrolepis cordifolia (L.) C. Presl & $\mathrm{T}$ & G & ANP & I, III & HUCS 41387 \\
\hline Nephrolepis exaltata (L.) Schott & $\mathrm{T}$ & G & NEO & III & PACA 74470 \\
\hline Nephrolepis pectinata (Willd.) Schott & $\mathrm{T}$ & G & NEO & II & ICN 129296 \\
\hline \multicolumn{6}{|l|}{ LYCOPODIACEAE } \\
\hline Lycopodiella alopecuroides (L.) Cranfill & $\mathrm{T}$ & G & NEO & I, II, III, IV, V & HUCS 41053 \\
\hline Lycopodiella tupiana (B. Øllg. \& P.G. Windisch) B. Øllg. & $\mathrm{T}$ & G & NEO-PAR & II & HAS 78174 \\
\hline Lycopodium clavatum $\mathrm{L}$. & $\mathrm{T}$ & G & $\cos$ & I, III & HUCS 41395 \\
\hline Palhinhaea cernua (L.) Franco \& Vasc. & $\mathrm{T}$ & $\mathrm{G} / \mathrm{W}$ & PAN & I, II, III & HUCS 41396 \\
\hline Phlegmariurus acerosus (Sw.) B.Øllg. & $\mathrm{E}$ & $\mathrm{F}$ & NEO & I & ICN 89978 \\
\hline Phlegmariurus fontinaloides (Spring) B.Øllg. & $\mathrm{E}$ & $\mathrm{F}$ & NEO-ATL & I & HAS 40598 \\
\hline Phlegmariurus heterocarpon (Fée) B.Øllg. & E & $\mathrm{F}$ & NEO-PAR & I, II & HAS 40596 \\
\hline Phlegmariurus mandiocanus (Raddi) B.Øllg. & $\mathrm{E}$ & F & NEO-PAR & I, II & ICN 178336 \\
\hline Phlegmariurus quadrifariatus (Bory) B.Øllg. & E & $\mathrm{F}$ & NEO-ATL & I & ICN 44523 \\
\hline Phlegmariurus reflexus (Lam.) B.Øllg. & $\mathrm{T}$ & $\mathrm{F}$ & NEO & II & PACA 905 \\
\hline Pseudolycopodiella caroliniana (Silveira) Holub & $\mathrm{T}$ & G & NEO & I, II, III, V & HUCS 41054 \\
\hline \multicolumn{6}{|l|}{ LYGODIACEAE } \\
\hline Lygodium volubile Sw. & $\mathrm{T}$ & $\mathrm{F}$ & NEO & I & HUCS 41393 \\
\hline \multicolumn{6}{|l|}{ MARATTIACEAE } \\
\hline \multicolumn{6}{|l|}{ MARSILEACEAE } \\
\hline Marsilea ancylopoda A. Braun & $\mathrm{T}$ & W & NEO & I, III, IV & HUCS 41269 \\
\hline Regnellidium diphyllum Lindm. & $\mathrm{T}$ & W & NEO-PAM & I, II, III, IV, V & HUCS 41468 \\
\hline \multicolumn{6}{|l|}{ OPHIOGLOSSACEAE } \\
\hline Cheiroglossa palmata (L.) C.Presl & $\mathrm{E}$ & $\mathrm{F}$ & PAN & I, II & ICN 178367 \\
\hline Ophioglossum crotalophoroides Walter & $\mathrm{T}$ & G & NEO & I, IV & HURG 115 \\
\hline Ophioglossum nudicaule L.f. & $\mathrm{T}$ & G & PAN & I, II, III, IV & ICN 47377 \\
\hline Ophioglossum reticulatum $\mathrm{L}$. & $\mathrm{T}$ & G & PAN & I, II, III & ICN 45109 \\
\hline \multicolumn{6}{|l|}{ OSMUNDACEAE } \\
\hline Osmunda regalis $\mathrm{L}$. & $\mathrm{T}$ & $\mathrm{G} / \mathrm{F} / \mathrm{W}$ & HOL & I, II, III, IV, V & HUCS 41052 \\
\hline Osmundastrum cinnamomeum (L.) C. Presl & $\mathrm{T}$ & $\mathrm{G} / \mathrm{F} / \mathrm{W}$ & HOL & III, IV & HUCS 41466 \\
\hline \multicolumn{6}{|l|}{ POLYPODIACEAE } \\
\hline Campyloneurum acrocarpon Fée & $\mathrm{T}$ & $\mathrm{F}$ & NEO-ATL & I & HUCS 41286 \\
\hline Campyloneurum austrobrasilianum (Alston) de la Sota & E & $\mathrm{F}$ & NEO-PAR & I, II, III & HUCS 39495 \\
\hline Campyloneurum lapathifolium (Poir.) Ching & $\mathrm{T} / \mathrm{E}$ & $\mathrm{F}$ & NEO & I & ICN 152403 \\
\hline Campyloneurum nitidum (Kaulf.) C. Presl & $\mathrm{T}$ & F & NEO & I, II, III, IV & HUCS 41482 \\
\hline Campyloneurum rigidum $\mathrm{Sm}$. & E & $\mathrm{F}$ & NEO-ATL & I & PACA 91198 \\
\hline Microgramma squamulosa (Kaulf.) de la Sota & $\mathrm{T} / \mathrm{E}$ & $\mathrm{G} / \mathrm{F}$ & NEO & I, II, III, IV, V & HUCS 38881 \\
\hline Microgramma vacciniifolia (Langsd. \& Fisch.) Copel. & $\mathrm{T} / \mathrm{E}$ & $\mathrm{G} / \mathrm{F}$ & NEO & I, II, III, IV, V & HUCS 37778 \\
\hline Niphidium crassifolium (L.) Lellinger & E & F & NEO & I, II & ICN 143984 \\
\hline Niphidium rufosquamatum Lellinger & E & $\mathrm{F}$ & NEO & I, II, III, IV & HUCS 38943 \\
\hline Pecluma chnoophora (Kunze) Salino \& Costa Assis & $\mathrm{T}$ & $\mathrm{F}$ & NEO-PAR & I & HUCS 41545 \\
\hline Pecluma paradiseae (Langsd. \& Fisch.) M.G. Price & $\mathrm{T}$ & F & NEO-ATL & I, II, III & HUCS 41542 \\
\hline Pecluma pectinatiformis (Lindm.) M.G.Price & E & $\mathrm{F}$ & NEO-PAR & I, II, III & ICN 168848 \\
\hline Pecluma recurvata (Kaulf.) M.G.Price & E & $\mathrm{F}$ & NEO-PAR & I & ICN 184455 \\
\hline
\end{tabular}


Table 1. Cont.

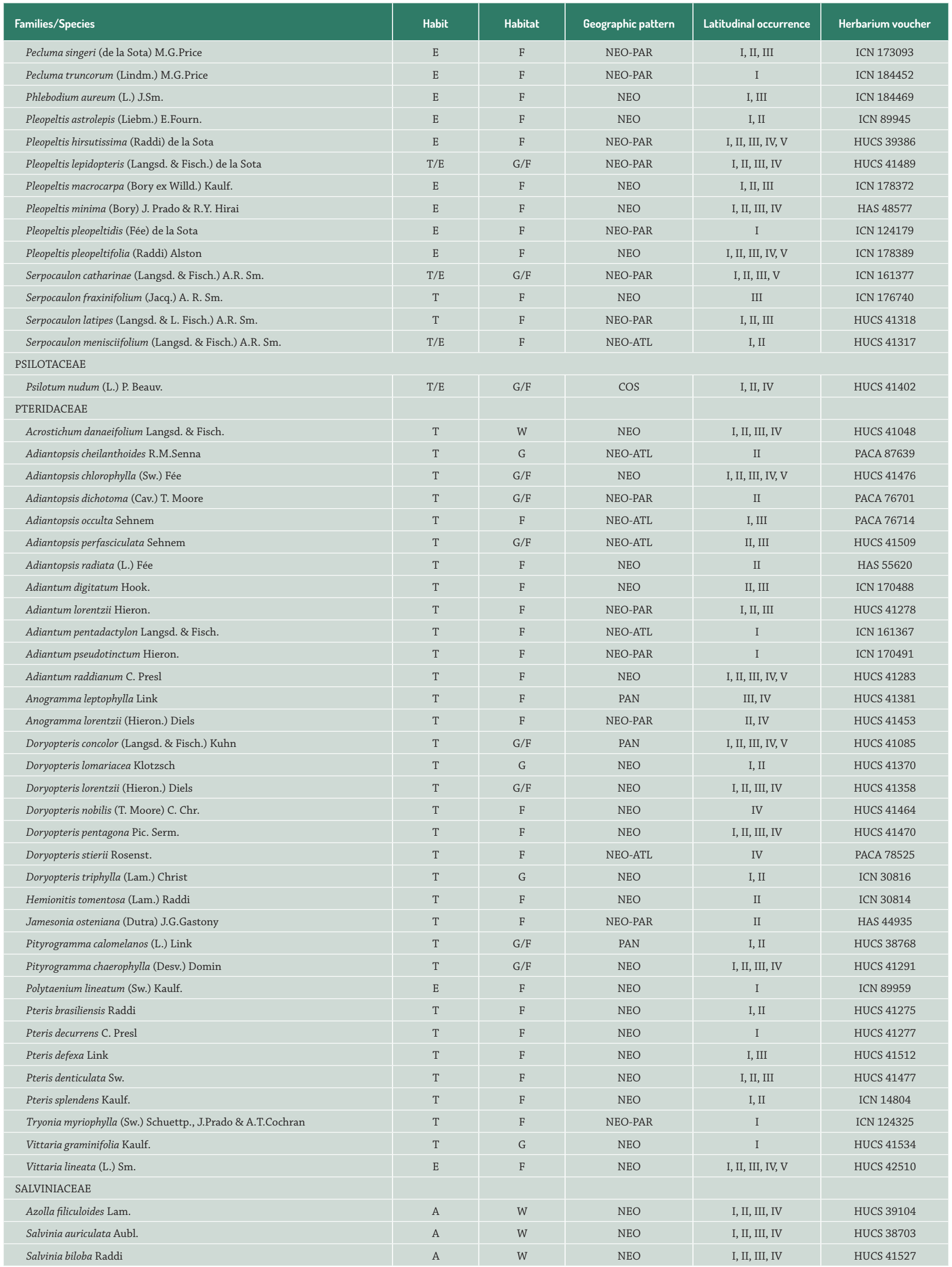


Table 1. Cont.

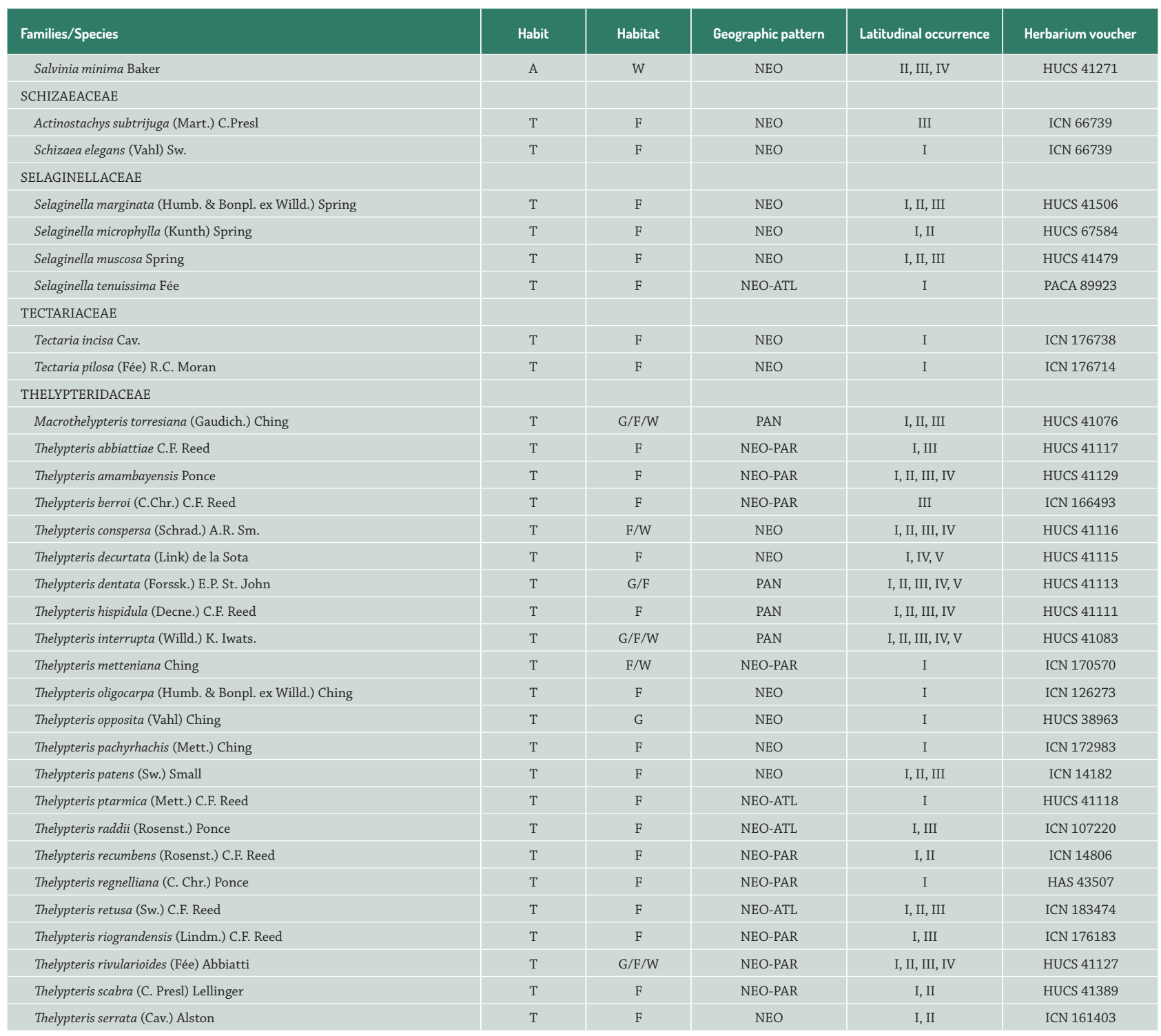

the largest values for species richness were: Thelypteris (22), Asplenium (17), Blechnum (12), Elaphoglossum (nine), Pecluma (eight), Pleopeltis (seven) and Doryopteris (seven), with the remaining genera varying from one to six species (Tab. 1).

Richness differed among the evaluated latitudinal ranges, with the number of taxa gradually decreasing from north-to-south with Range I having 198 species, while Range $\mathrm{V}$ had only 28. Of the total 223 species, only 21 occurred throughout the entire study area (Tab. 1). Large reductions in floristic richness occurred between latitudinal Ranges III and IV, and between Ranges IV and V, with a decrease of $46 \%$ and $51 \%$, respectively. A $43 \%$ reduction in floristic richness was observed between Ranges I and II. At the northern extreme of the study area (Range I), $34 \%$ of the richness corresponded to species that occur exclusively in that portion of the area, while in ranges to the south exclusive species comprised less than $10 \%$, reaching $0 \%$ in the extreme South (Range V) (Fig. 2).
The gradual decrease in species richness along the Coastal Region was observed for all families, but particularly Polypodiaceae, Pteridaceae, Aspleniaceae and Thelypteridaceae, which represented more than $80 \%$ of the reduction. Some families such as Lygodiaceae, Marattiaceae and Tectariaceae were restricted to the extreme north. Others, such as Lindsaeaceae, Hymenophyllaceae, Lomariopsidaceae, Selaginellaceae, Dicksoniaceae and Schizaeaceae, occurred exclusively in the three northern-most latitudinal ranges (Fig. 3). Terrestrial taxa predominated with 162 species (75\%), followed by epiphytes with 33 species (12\%), while 24 species (10\%) exhibited two different habits (epiphytic and terrestrial). Aquatic taxa were represented by four species (7\% of total) (Fig. 4). With an increase in latitude, there was an increase in terrestrial species richness and a reduction in epiphytes. At the extreme north, the contingent of terrestrial species reached $70 \%$, while at the extreme South it amounted to $78 \%$, with a reduction of ca. $6 \%$ of 


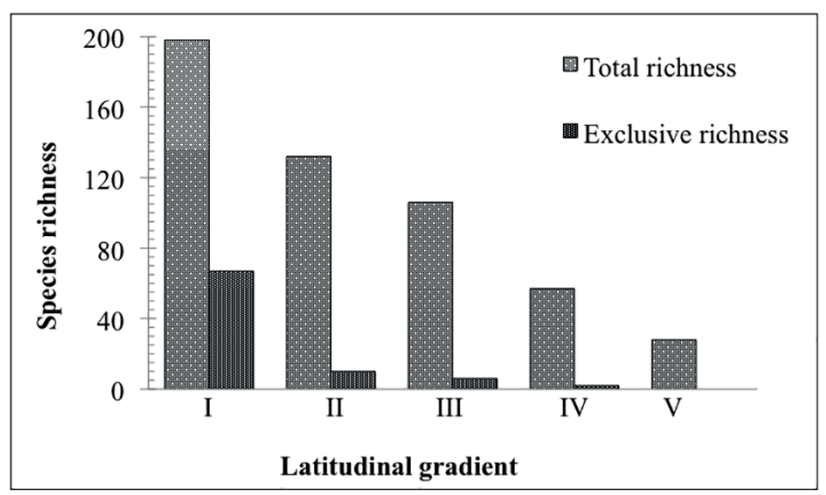

Figure 2. Species richness for ferns and lycophytes found in each latitudinal range sampled.

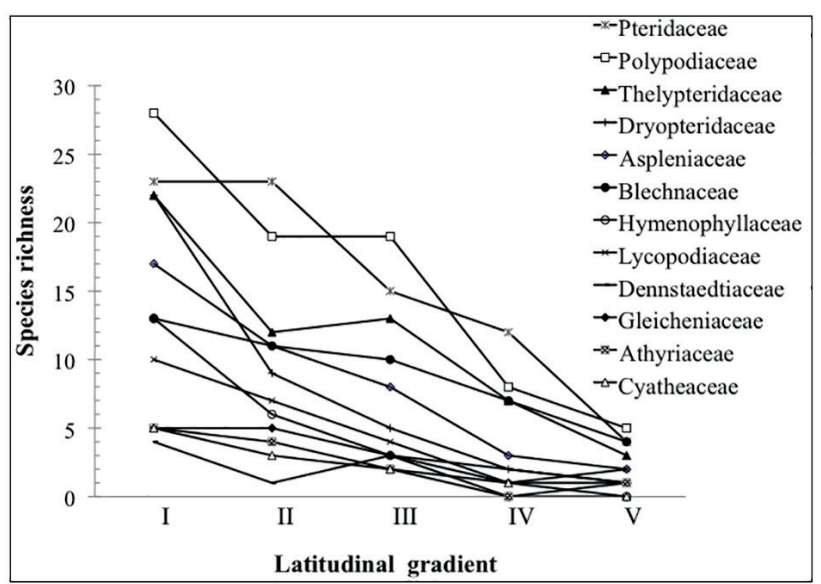

Figure 3. Species richness by botanical family found in each latitudinal range. Note the reduction in the number of species from north-to-south in the CRRS.

epiphytic species in the north-to-south direction. Species that exhibited more than one habit were found mostly (80\%) in forest environments.

A total of 159 (71\%) species occurred exclusively in forest environments, while 26 were found in grassland formations. Some species were found both in forest and grassland habitats (15 spp., 15\%). Nine species were present in wetland environments, and an equal number of species occurred in all three environments (forest, grassland and wetland). Blechnum brasiliense, Thelypteris conspersa and Thelypteris metteniana, occurred in forest and wetland habitats, whereas Blechnum schomburgkii and Palhinhaea cernua were found in grassland and wetland environments (Tab. 1). Differences in preference patterns for vegetation formations were identified over the studied profile (Fig. 5), with a decrease of forest species $(-40 \%)$ and the increase in grassland/forest $(+20 \%)$ and grassland/forest/wet land $(+18 \%)$ species in the north-to-south direction.

Taxa with wide global distributions were the most commonly observed with 140 species (63\%), of which 113 were neotropical (51\%), 17 pantropical, and two (Lycopodium

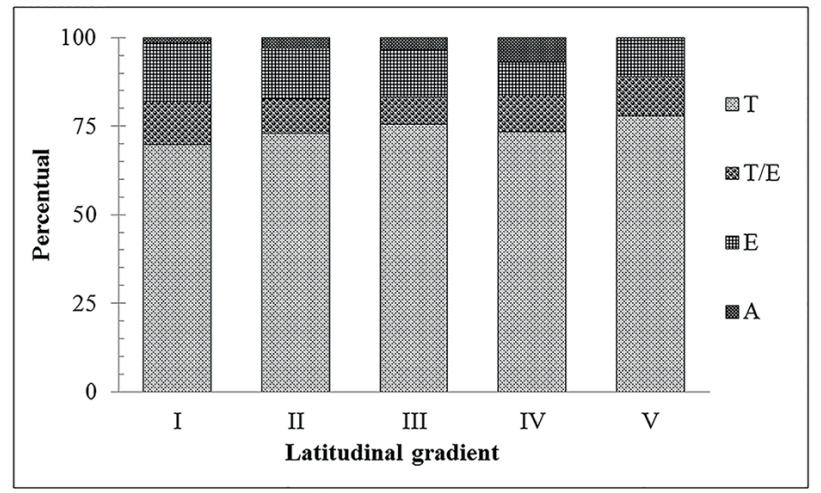

Figure 4. Preferred habit of fern and lycophyte species in different latitudinal ranges of the CRRS. I, II, III, IV and V: latitudinal bands of the CRRS. E: epiphytic ferns; T: terrestrial ferns; T/E: epiphytic and terrestrial ferns; A: aquatic ferns.

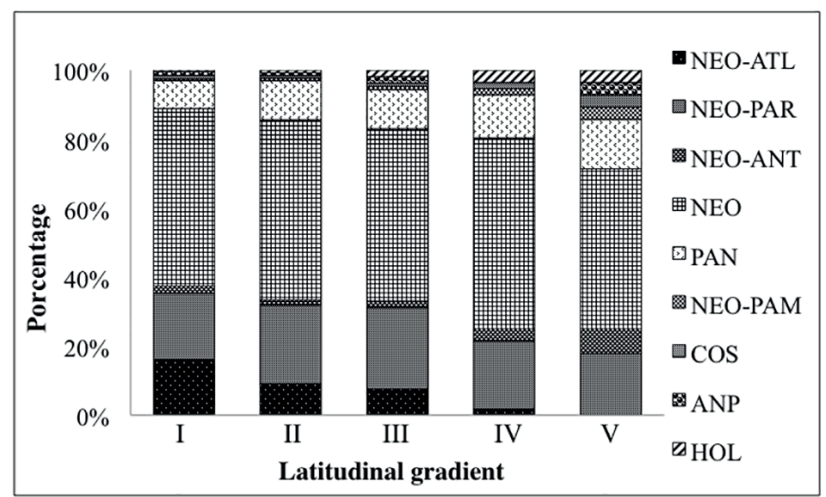

Figure 5. Distribution of fern and lycophyte species in the different latitudinal ranges of the CRRS. I, II, III, IV and V: latitudinal ranges of the CRRS. CO: Cosmopolitan; AMP: Amphipacific; HOL: Holartic; PAN: Pantropical; NEO: Neotropical; NEO-PAM: Neotropical-Pampeana; NEO-ANT: Neotropical-Antartic; NEOPAR: Neotropical-Paranaense; NEO-ATL: Neotropical-Atlantic.

clavatum and Psilotum nudum) cosmopolitan. The species Deparia petersenii and Nephrolepis cordifolia are amphipacific; Osmunda regalis and Osmundastrum cinnamomeum are Holarctic; and Blechnum cordatum, Lophosoria quadripinnata, Hymenophyllum caudiculatum and Equisetum giganteum are Neotropical-Antarctic. Species with restricted distributions represented 37\% (83 species) with 44 being NeotropicalParanaense, 38 Neotropical-Atlantic and one NeotropicalPampean (Regnellidium diphyllum) (Tab. 1).

Floristic similarity analysis among the five latitudinal ranges revealed two floristically distinct regions in the CRRS: one formed by Ranges IV and V (South center and extreme South) and another formed by Ranges I, II and III (Middle center, North center and extreme North) (Fig. 6). Although they are grouped together, Ranges IV and V had low floristic similarity (53\%), as did Ranges I, II and III (41\%). Ranges I and II had 70\% similarity, while ranges II and III were 73\% similar. Only 21 species were common to all areas (Tab. 1). 


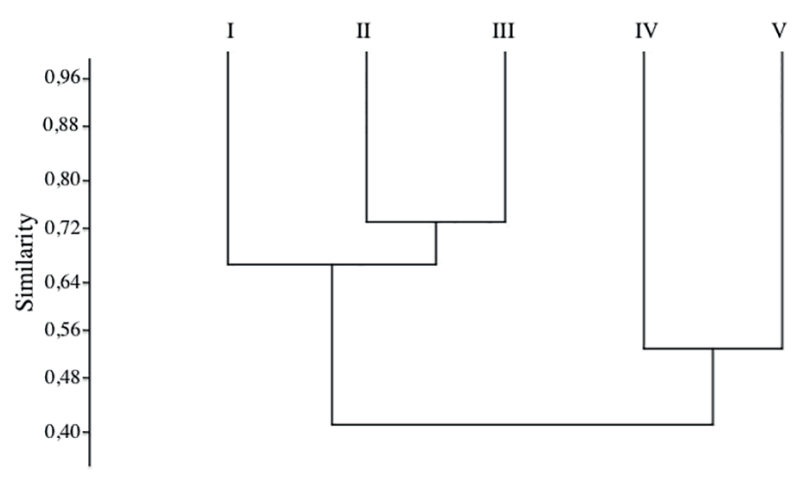

Figure 6. Similarities among the five latitudinal ranges (Sørensen Similarity Indices) showing the floristic distinction between the group of Ranges I, II, III and the group of Ranges IV and V of the CRRS.

\section{Discussion}

The species richness observed in this study corresponds to about $36 \%$ of the pteridophytic flora listed by Sehnem (1977) for the Southern Region of Brazil and $49 \%$ of that listed in Prado \& Sylvestre (2015) for the state of Rio Grande do Sul. Most floristic studies on coastal ferns have been restricted to vegetation fragments, parks, conservation units or some specific synusiae (Behar \& Viégas 1992; Labiak \& Prado 1998; Kersten \& Silva 2001; Santos et al. 2004; Dittrich et al. 2005; Athayde Filho \& Windisch 2006; Gonzatti et al. 2014b). Despite having an extensive survey area, the richness observed in the present study is lower than that found by other authors in smaller tropical rain and Araucaria forest areas (Mynssen \& Windisch 2004; Schwartsburd \& Labiak 2007; Salino \& Almeida 2008; Prado \& Labiak 2009; Gasper \& Sevegnani 2010; Souza et al. 2012), all of which were in lower latitudes.

In spite of the existence of a mountain chain (Serra do Mar), which harbors high fern and lycophyte species richness and serves as a corridor connecting the Southeastern and Southern Regions of Brazil (Tryon \& Tryon 1982; Windisch 1996), a pronounced floristic reduction is evident between the two regions (Fig. 7). As an example, several fern and lycophyte genera, such as Doryopteris (Tryon 1942), Phlegmariurus (Windisch 1996) and Asplenium (Sylvestre \& Windisch 2003), have high species richness and endemism in the Atlantic Forest of southeastern Brazil, but are strongly affected by latitudinal changes and experience a reduction in floristic richness towards the southern sector of the Atlantic Forest. However, the floristic richness found in CRRS is $82 \%$ higher than the fern and lycophyte flora of Uruguay further to the south (Legrand \& Lombardo 1958; Zuloaga et al. 2008), indicating the continuation of floristic reduction through Uruguay to southern Argentina (Ponce et al. 2002).

In the Neotropics, plant species richness is more strongly correlated with precipitation than edaphic variation (Gentry 1988). In the Atlantic Forest, patterns of floristic change of arboreal vegetation along latitudinal gradients have been attributed to variation in temperature and rainfall distribution. These climatic variables are important in differentiating richness and floristic composition of families, genera and species (Oliveira-Filho \& Fontes 2000). The same authors verified that rainfall and temperature increments influence processes of tropicalization and changes in vegetation types, mostly when associated with increased latitude. For Atlantic Forest ferns and lycophytes, variables such as precipitation and evapotranspiration determine plant species composition in distinct vegetation types, as also discussed by Gasper et al. (2013).

Large-scale changes in diversity related to latitudinal gradients have been previously reported for ferns and lycophytes by Moran (2008), with several examples of the concentration of species richness in tropical regions with accentuated decreases towards both poles. According to this author, in South America, particularly in the tropical region, fern and lycophyte richness can reach 2,000 species, while in temperate regions it is only 79 species. Sato (1982) points out that in Japan, species richness decreases with increasing latitude, mostly due to climatic conditions.

Through the southern portion of CRRS, there was a reduction of the floristic richness of most families and genera. In addition to the reduction of fern and lycophyte total diversity, the incidence of species with NeotropicalAtlantic and Neotropical-Paranaense geographical distribution patterns was strongly affected. Taxa that maintain their distributions along the profile (21 spp.) have a wide Neotropical or global distribution (Tab. 1), and their occurrence extends to Uruguay (Legrand \& Lombardo 1958; Zuloaga et al. 2008).

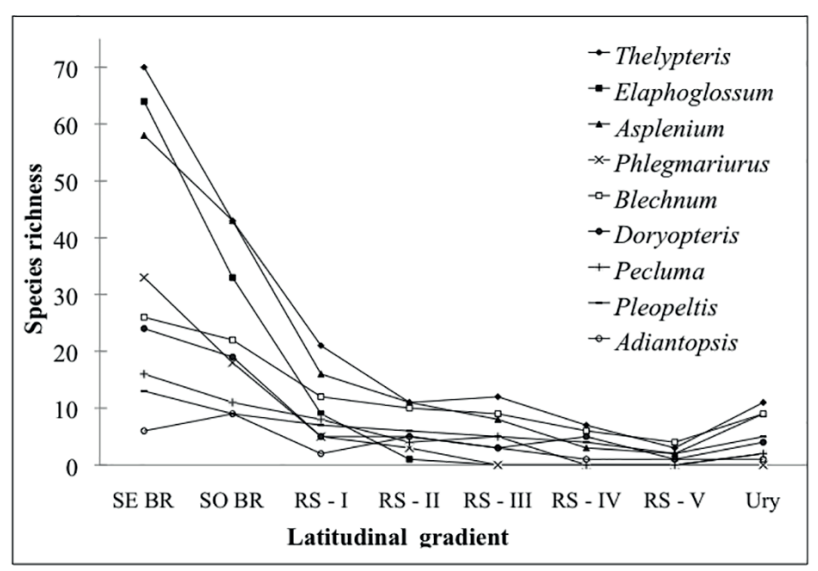

Figure 7. Pattern of decreasing species richness for some genera of ferns and lycophytes present in southeastern and southern Brazil, as well as along the CRRS and Uruguay. SE BR (southeastern Brazil), SO BR (southern Brazil), RS I, II, III, IV and V (latitudinal ranges of the CRRS) and Ury (Uruguay). Data according to Prado \& Sylvestre (2015) and Zuloaga et al. (2008). 
The extended distribution of many tropical species in the CRRS can be interrupted by alterations to the northto-south forest continuity. The transition from tropical rain forest to other vegetation types such as grasslands, peat forests, sandy forests, seasonal forests and riparian habitats (Waechter 1990) can affect distribution patterns and inhibit dispersal of ferns and lycophytes. In Rio Grande do Sul, tropical rain forest reaches its southern limit at the $30^{\circ} \mathrm{S}$ parallel in the region of Osório - RS (Rambo 1951; 1954; Lorscheitter 2003). These formations develop on the extreme southern slopes of the "Serra do Mar" and on the eastern face of "Serra Geral". Due to the climatic conditions of temperature and precipitation, as well as the environmental heterogeneity of vegetation and substrates, the development of larger forests with tropical species are allowed, as is the dispersal of northern floristic components (Rambo 1951; Klein 1984; Waechter 1985; Waechter 1990). These characteristics of environment heterogeneity are fundamental to increasing fern and lycophyte diversity in the Atlantic Forest (Windisch 1992; Dittrich et al. 2005), and they were not observed in CRRS Ranges III, IV and V.

Phytogeographically, the latitude $30^{\circ} \mathrm{S}$ defines the limit between the Atlantic and Paranaense provinces where pluvial and subtropical forests (Atlantic Forest) find their southern limit, and are gradually replaced by herbaceous elements of the Pampa biome (Cabrera \& Willink 1980). Sota (1973) considers that the Pampa, along with the Chaco, are barriers separating the center of fern and lycophyte diversity in southern Brazil from the Argentinian and Chilean centers of diversity. According to Prado \& Hirai (2014), the Pampa biome is the poorest in fern and lycophyte diversity, with only $0.5 \%$ of the floristic richness found in the Atlantic Forest.

This same reduction in diversity has been reported previously by other authors. Rambo (1950; 1951; 1954; 1956) observed structural and floristic modifications to vegetation along the Coastal Region, attributing the decrease in species richness to the dispersal processes that occurred throughout the region he referred to as "Porta de Torres" ("Torres migrational gate"). This latitudinal gradient was later observed by Waechter (unpublished data) in a study of vascular epiphytes, who found a $93.7 \%$ reduction in richness between latitudinal Range I and Range V. In his work with epiphytic orchids, Waechter (1998) found that there is a total reduction in species richness along the CRRS, a $88 \%$ reduction between Range I and Range II, and that no species reached south of parallel $33^{\circ} \mathrm{S}$. Of the 61 genera he studied, only four are found in Uruguay and one in the province of Buenos Aires (Argentina).

Among the factors that influence floristic change in the north-to-south direction of the CRRS, Waechter (1990) highlights climatic discontinuity along the region. The author noted that the decrease in rainfall and temperature going south causes an increase in the number of cold days and annual frost events. This, in turn, results in changes to vegetation communities, causing insularization and discontinuity of the arboreal component, thus interfering in the dispersal routes of tropical plant species.

Although a strong floristic discontinuity has been reported for the region of parallel $30^{\circ} \mathrm{S}$ (Waechter 1990; 1998), our data indicate that for ferns and lycophytes this discontinuity occurs mostly from parallel $31^{\circ}$ southwards (Fig. 7), where a reduction in species richness and the differentiation of the floristic elements in Ranges I, II, and II vs. Ranges IV and V were observed. These results can be associated with the high dispersal capacity of fern and lycophyte spores, thereby finding niches with favorable conditions for their establishment and reproduction (Tryon 1970; Wolf et al. 2001), or simply forest connections (present and past) that allowed for a broader distribution.

Our results indicate that more species occur in more than one environment (forest/grassland or forest/grassland/wet land) with increasing latitude, and that there is a decrease of strict forestalls. The strong dependence of ferns on forest environments can be related to the group's evolutionary history, which suggests that $80 \%$ of current ferns evolved in forest environments after the angiosperm radiation ca. 100-65 mya (Schneider et al. 2004).

Another north-to-south floristic change in the CRRS can be seen in the reduction of epiphytic species in Range $\mathrm{V}$ with the concomitant prevalence of terrestrial species (Fig. 5). Beyond the need for adequate ecological conditions (Sota 1971; Benzing 1987), there is the requirement of host plant availability for the establishment of epipytic species (Waechter unpublished data).

Some species restricted to Range I, such as Vandenboschia radicans, Lomariopsis marginata, Mickelia scandens, Polybotrya cylindrica, Olfersia cervina, are hemiepiphytes, that begin development on the ground and later climb host plants. These species are extremely dependent on environments with high levels of humidity such as is found in the interior of forests without edge effects and external light incidence (Orihuela \& Waechter 2010; Orihuela et al. 2013).

Decreased amounts of rainfall and the existence of a drier season in the extreme south can limit the establishment and development of fern and lycophyte flora. Ranal (1995a) points out that fern spore germination, as well as the development of the gametophyte and sporophyte, are strongly affected by desiccation. In experiments focusing on survival, Ranal (1995b) shows that $30 \%$ of fern gametophyte deaths are due to desiccation. Watkins et al. (2007) demonstrated that the gametophytes of xerophytic species, as well as epiphytic and some terrestrial species, are better adapted to survive conditions of scarce water, contrary to mesophytic species, which cannot undergo periodic variations in their water content.

Other features inherent to the reproductive success of many ferns and lycophytes can be decisive in their establishment in particular habitats. Although this group of plants is capable of dispersing spores over long distances (Holttum 1938) and can form spore banks in the ground (Ranal 2003), the spores may not encounter 
the microclimatic (temperature, humidity and luminosity) and biotic conditions (mycorrhizal associations) needed for germination (Williams 1938; Sheffields 1996). Furthermore, gametophytes, even when possessing adaptations to desiccation and variable conditions of $\mathrm{pH}$, soil nutrition, temperature and luminosity (Farrar et al. 2008), can suffer from insufficient availability of free water in the environment, which in and of itself can be a limiting factor to their establishment. Despite the fact that some fern species have strategic adaptations for independent gametophytic reproduction (apogamy, clonal reproduction by gemmae, $\mathrm{pH}$ metamorphosis) the presence of water is still a requirement for the successful sexual reproduction of the gametophyte of most fern and lycophyte species (Page 2002). According to Holttum (1938), the majority of fern and lycophyte spores germinate in forest environments, and to occupy other environments with adverse conditions they need specific adaptations.

The occurrence of ferns in wetland and grassland environments is also related to expansion of these vegetation formations in the north-to-south direction, with the expansion of water bodies in wetland-region lagoons and natural grasslands most frequent in Range V. For example, Blechnum brasiliense has adapted to a variety of environments that differ in their edaphic composition, vegetation formations and microclimate conditions (Silva et al. 2013).

Data compiled by Nimer (1990) and Moreno (1961), point out clear differences in the climatic patterns of the two extremes of CRRS. According to these authors, the average annual precipitation can be up to $300 \mathrm{~mm}$ /year lower and the average temperature about $2^{\circ} \mathrm{Clower}$ in Range V. Furthermore, the average number of days with frost increases from three to 15 days in the extreme south (Range V). This southern, more temperate climate can explain the presence of species with Neotropical-Antarctic or Holarctic distribution patterns in the floristic composition of Range $\mathrm{V}$, such as Osmunda regalis and Equisetum giganteum.

Studies published by Bremer \& Jongejans (2010) on the population dynamics of Asplenium scolopendrium show the negative effect of frost on the survival and, consequently, the retrogression of this species. According to these authors, frost affects fern sporophytes in three ways: direct mortality by freezing caused by wind, soil freezing, and hydric unavailability caused by ice. In populations submitted to 22 continuous days with frost, mortality reached $38 \%$. In order for this species to occur in these regions of low temperatures and frost, adaptations at all development stages are required. In several cases phenological changes take place that permit survival and ensure the reproductive success during cold periods (Sato \& Sakai 1980; Sato \& Sakai 1981; Sato 1982).

Although the best temperatures for spore germination and gametophyte growth are generally considered to be between $20^{\circ}$ and $30^{\circ} \mathrm{C}$ (Miller 1968), various exceptions have been observed. In northeastern United States, gametophytes of the genus Vittaria Sm. can become established in certain environments, form extensive populations through asexual reproduction by apogamy and persist during prolonged frost while the sporophytes do not survive, dying at the beginning of their development (Farrar 1978). These reports were also corroborated by Sato \& Sakai (1980) for many Asiatic species, where the gametophytic phase can resist temperatures below $-40^{\circ} \mathrm{C}$, while their sporophytes do not survive in temperatures below $0^{\circ} \mathrm{C}$. This limiting factor can be associated with the decrease of species richness (at least in the sporophyte phase) in the extreme south of CRRS, where the species are more adapted to such conditions, such as Osmundastrum cinnamomeum whose sporophyte can resist $-10^{\circ} \mathrm{C}$ (Sato 1982 ).

Sehnem (1977) suggested that the low richness of ferns and lycophytes in some regions of the state of Rio Grande do Sul is influenced by the reduced amount of time for the migration of additional species (recent paleogeographic evolution) and, consequently, the limited distribution of these species in the extreme south. This phenomenon may explain the decrease of fern and lycophyte species in the temperate floras of the "Southern Cone", which can have three to four times fewer species than tropical floras such as in southeastern Brazil (Ponce et al. 2002).

The impoverishment of the extreme southern flora of CRRS may also be related to past paleoenvironmental conditions. Paleogeographic and palynological evidence point to the existence of an arid climate and the prevalence of grassland vegetation across southern Brazil that persisted at least until the beginning of the Holocene, when the migration of the tropical vegetation of southeastern Brazil to CRRS started (Ab'Sáber 1977; Ledru et al. 1998; Lorscheitter 2003).

Rising humidity patterns in the past 4,000 years show the expansion of fern and lycophyte communities in "Laguna dos Patos" (Middle center of the Coastal Region) (Lorcheitter 2003), which could not have occurred in the extreme South, due to climatic conditions. Recent palynological data from the Holocene period (Masetto \& Lorcheitter 2014) establish the presence of taxa currently not found in the region, indicating alterations in the current floristic composition, or in the process of long distance dispersal.

The most striking outcome of our study was the high floristic richness present in the Coastal Region of the state of Rio Grande do Sul and the high reduction in species richness of ferns and lycophytes along the north-south extremes of RCRS. There are a variety of factors, including climatic limitations, dynamic phytogeography and the biology of ferns and lycopods themselves that have been considered in explaining these observations.

\section{Acknowledgments}

The authors thank the curators of the cited herbaria for their welcoming assistance and our colleague Flávia Diniz da 
Silva for assistance in the field work. The CAPES and CNPq for providing a scholarship to the first author and research grant to the third author.We thank the "Universidade Federal do Rio Grande do Sul" (UFRGS) and the "Universidade de Caxias do Sul" (UCS) for permitting the use of their facilities. We are grateful to all the reviewers of this manuscript.

\section{References}

Ab’Sáber AN. 1977. Os domínios morfoclimáticos na América do Sul. Primeira aproximação. Geomorfologia 52: 1-23.

Alvares CA, Stape JL, Sentelhas PC, Gonçalves JLM, Sparovek G. 2013. Köppen's climate classification map for Brazil. Meteorologische Zeitschrift 22: 711-728.

Athayde-Filho FP, Windisch PG. 2006. Florística e aspectos ecológicos das pteridófitas em uma floresta de Restinga no Estado do Rio Grande do Sul, Brasil. Iheringia, Serie Botânica 61: 63-71.

Barrington DS. 1993. Ecological and historical factors in fern biogreography. Journal of Biogeography 20: 275-280.

Becker DFP, Cunha S, Goetz MNB, Kieling-Rubio MA, Schmitt JL. 2013. Florística de samambaias e licófitas em fragmento florestal da bacia hidrográfica do Rio dos Sinos, Caraá, RS, Brasil. Pesquisas, Botânica 64: 273-28.

Behar L,Viégas GMF. 1992. Pteridophyta da restinga do Parque Estadual de Setiba, Espírito Santo. Boletim do Museu de Biologia Mello Leitão 1: 39-59.

Benzing DH. 1987. Vascular epiphytism: taxonomic participation and adaptive diversity. Annals of the Missouri Botanical Garden 74: 183404.

Bremer P, Jongejans E. 2010. Frost and forest stand effects on the population dynamics of Asplenium scolopendrium. Population Ecology 52: 211-222.

Buchmann FSC, Caron F, Lopes RP, Ugri A, Lima LGL. 2009. Panorama geológico da Planície Costeira do Rio Grande do Sul. In: Ribeiro AM, Bauermann SG, Scherer CS. (eds.) Quaternário do Rio Grande do Sul: integrando conhecimentos. 1st. edn. Porto Alegre, Sociedade Brasileira de Paleontologia. p. 35-56.

Bueno RM, Senna RM. 1992. Pteridófitas do Parque Nacional dos Aparados da Serra. I. Região do Paradouro. Caderno de Pesquisas, Série Botânica 4: 5-12.

Cabrera Al, Willink A. 1980. Biogeografia de America Latina. Washington, OEA.

Cochran AT, Prado J, Schuettpelz E. 2014. Tryonia, a new taenitidoid fern genus segregated from Jamesonia and Eriosorus (Pteridaceae). PhytoKeys 35: 23-43.

Cordeiro JLP, Hasenack H. 2012. Cobertura vegetal atual do Rio Grande do Sul. In: Pillar VP, Müller SC, Castilhos ZMS, Jacques AVA. (eds.) Campos Sulinos: conservação e uso sustentável da biodiversidade. Brasília, MMA. p. 285-300.

Dittrich VAO, Waechter JL, Salino A. 2005. Species richness of pteridophytes in a montane Atlantic rain forest plot of Southern Brazil. Acta Botanica Brasilica 19: 519-525.

Embrapa - Empresa Brasileira de Pesquisa Agropecuária. 2006. Sistema Brasileiro de Classificação de Solos. 2nd. edn. Rio de Janeiro, Embrapa.

Farrar DR. 1978. Problem in the identity and origin of the Appalachian Vittaria gametophytes, a sporophyteless fern of the eastern United States. American Journal of Botany 65: 1-12.

Farrar DR, Dassler C, Watkins JRJA, Skelton C. 2008. Gametophyte ecology. In: Ranker TA, Haufler CH. (eds.) Biology and evolution of ferns and Lycophytes. New York, Cambridge University Press. p. 222-256.

Fiaschi P, Pirani JR. 2009. Review of plant biogeographic studies in Brazil. Journal of Systematic and Evolution 47: 477-496.

Filgueiras TS, Brochado AL, Nogueira PE, Guala II GF. 1994. Caminhamento: um método expedito para levantamentos florísticos qualitativos. Cadernos de Geociências 2: 39-43.

Gasper AL, Sevegnani L. 2010. Lycophyta e samambaias do Parque Nacional da Serra do Itajaí, Vale do Itajaí, SC, Brasil. Hoehnea 37: 755-767.
Gasper AL, Eisenlohr PV, Salino A. 2013. Climate-related variables and geographic distance affect fern species composition across a vegetation gradient in a shrinking hotspot. Plant Ecology and Diversity 8: 25-35.

Gentry AH. 1988. Changes in plant community diversity and floristic composition on environmental and geographical gradients. Annals of Missouri Botanical Garden 75: 1-34.

Gonzatti F, Valduga E, Wasum R, Scur L. 2014a. Florística e aspectos ecológicos de samambaias e licófitas em remanescentes de matas estacionais deciduais da serra gaúcha, Rio Grande do Sul, Brasil. Revista Brasileira de Biociências 12: 90-97.

Gonzatti F, Valduga E, Wasum R, Scur L. 2014b. Florística e aspectos ecológicos de licófitas e samambaias do litoral médio do Rio Grande do Sul, Brasil. Revista Brasileira de Biociências 12: 215-225.

Hammer $\varnothing$, Harper DAT, Ryan PD. 2001. PAST: Paleontological Statistics software package for education and data analysis. Palaeontologia Eletronica 4: 1-9.

Holttum RE. 1938. The ecology of tropical pteridophytes. In: Verdoom Fr. (ed.) Manual of pteridology. The Hague, Martinus Nijhoff. p. 420-450.

Kersten RA, Silva SM. 2001. Composição florística e estrutura do componente epifítico vascular da planície litorânea na Ilha do Mel, Paraná, Brasil. Revista Brasileira de Botânica 24: 213-226.

Kessler M. 2001. Pteridophyte species richness in Andean forest in Bolivia. Biodiversity and Conservation 10: 1473-1495.

Kessler M, Kluge J, Hemp A, Ohlemüller R. 2011. A global comparative analysis of elevational species richness patterns of ferns. Global Ecology Biogeography 20: 868-880.

Klein RM. 1984. Aspectos dinâmicos da vegetação do Sul do Brasil. Sellowia 36: 5-54.

Labiak PH, Prado J. 1998. Pteridófitas epífitas da Reserva Volta Velha, Itapoá, Santa Catarina, Brasil. Boletim do Instituto de Botânica 11: 1-79.

Ledru MP, Labouriau MLS, Lorscheitter ML.1998. Vegetation dynamics in Southern and Central Brazil during the last 10,000 yr.b.p. Review of Palaeobotany and Palynology 99: 131-142.

Legrand D, Lombardo A. 1958. Flora del Uruguay: I Pteridophyta. Montevideo, Museu Nacional de História Natural.

Lehn, CR, Leuchtenberger C, Hansen MAF. 2009. Pteridófitas ocorrentes em dois remanescentes de Floresta Estacional Decidual no Vale do Taquari, Estado do Rio Grande do Sul, Brasil. Iheringia. Serie Botânica 64: 23-31.

Lorscheitter ML. 2003. Contribution to the Holocene history of Atlantic Rain Forest in the Rio Grande do Sul state, southern Brazil. Revista del Museo Argentino de Ciencias Naturales 5: 261-27.

Lorscheitter ML, Ashraf AR, Bueno RM, Mosbrugger V. 1998. Pteridophyte spores of Rio Grande do Sul flora, Brazil. Part I. Palaeontographica Abteilung B: Palaöphytologie 246: 1-113.

Lorscheitter ML, Ashraf AR, Windisch PG, Mosbrugger V. 1999. Pteridophyte spores of Rio Grande do Sul flora, Brazil. Part II. Palaeontographica Abteilung B: Palaöphytologie 251: 71-235.

Lorscheitter ML, Ashraf AR, Windisch PG, Mosbrugger V. 2001. Pteridophyte spores of Rio Grande do Sul flora, Bazil. Part III. Palaeontographica Abteilung B: Palaöphytologie 260: 1-165.

Lorscheitter ML, Ashraf AR, Windisch PG, Mosbrugger V. 2002. Pteridophyte spores of Rio Grande do Sul flora, Brazil. Part IV. Palaeontographica Abteilung B: Palaöphytologie 263: 1-159.

Lorscheitter ML, Ashraf AR, Windisch PG, Mosbrugger V. 2005. Pteridophyte spores of Rio Grande do Sul flora, Brazil. Part V. Palaeontographica Abteilung B: Palaöphytologie 270: 1-180.

Lorscheitter ML, Ashraf AR, Windisch PG, Mosbrugger V. 2009. Pteridophyte spores of Rio Grande do Sul flora, Brazil. Part VI. Palaeontographica Abteilung B: Palaöphytologie 281: 1-96.

Mallmann IT, Schmitt JL. 2014. Riqueza e composição florística da comunidade de samambaias na mata ciliar do Rio Cadeia, Rio Grande do Sul, Brasil. Ciência Florestal 24: 97-109.

Masetto E, Lorscheitter ML. 2014. Palynomorphs in Holocene sediments from a paleolagoon in the coastal plain of extreme southern Brazil. Acta Botanica Brasilica 28: 165-175.

Miller JH. 1968. Fern gametophytes as experimental material. Botanical Review 34: 361-440. 
MMA - Ministério do Meio Ambiente. 2000. Avaliação e ações prioritárias para a conservação da biodiversidade da Mata Atlântica e Campos Sulinos. Brasília,MMA/SBF.

Mondin CA, Silveira NJE. 1989. Levantamento florístico do Parque Estadual do Espigão Alto, RS, BR: I. Relação preliminar das pteridófitas. Loefgrenia 96: 1-5.

Moran RC. 2008. Diversity, biogeography and floristic. In: Ranker TA, Haufler CH. (eds.) Biology and evolution of ferns and lycophytes. Cambridge, Cambridge University Press. p. 367-394.

Moran RC, Labiak PH, Sundue M. 2010. Synopsis of Mickelia, a newly recognized genus of bolbitidoid ferns (Dryopteridaceae). Brittonia 62: 337-356.

Moreno JA. 1961. Clima do Rio Grande do Sul. Porto Alegre, Secretaria da Agricultura.

Moser JM. 1990. Solos. In: Instituto Brasileiro de Geografia e Estatística (ed.), Geografia do Brasil: região Sul. Rio de Janeiro, IBGE. p. 95-111.

Müller SC, Waechter JL. 2001. Estrutura dos componentes herbáceo e arbustivo de uma floresta costeira subtropical. Revista Brasileira de Botânica 24: 395-406.

Mynssen CM, Windisch PG. 2004. Pteridófitas da Reserva Rio das Pedras, Mangaratiba, RJ, Brasil. Rodriguésia 55: 125-156.

Nettesheim FC, Damasceno E, Sylvestre L. 2014. Different slopes of a mountain can determine the structure of ferns and lycophytes communities in a tropical forest of Brazil. Anais da Academia Brasileira de Ciências 86: 199-210.

Neumann MK, Schneider PH, Schmitt JL. 2014. Phenology, caudex growth and age estimation of Cyathea corcovadensis (Raddi) Domin (Cyatheaceae) in a subtropical forest in southern Brazil. Acta Botanica Brasilica 28: 274-280.

Nimer E. 1990. Clima. In: Instituto Brasileiro de Geografia e Estatística (ed.) Geografia do Brasil: região Sul. Rio de Janeiro, IBGE. p. 151-187.

Oliveira-Filho AT, Fontes MA. 2000. Patterns of floristic differentiation among Atlantic Forest in Southeastern Brazil and the influence of climate. Biotropica 32: 793-810.

Øllgaard B. 2012. Nomenclatural changes in Brazilian Lycopodiaceae. Rodriguésia 63: 479-482.

Orihuela RLL, Waechter JL. 2010. Host size and abundance of hemiepiphytes in a subtropical stand of Brazilian Atlantic Forest. Journal of Tropical Ecology 26: 119-122.

Orihuela RLL, Molz M, Waechter JL. 2013. Links between environmental factors and hemiepiphytes along a slope of subtropical Atlantic forest. Nordic Journal of Botany 31: 1-11.

Overbeck GE, Müller SC, Fidelis A, et al. 2012. Os campos sulinos: um bioma negligenciado. In: Pillar VP, Müller SC, Castilhos ZMS, Jacques AVA. (eds.) Campos Sulinos: conservação e uso sustentável da biodiversidade. Brasília, MMA. p. 26-42.

Paciencia MLB, Prado J. 2005. Effects of forest fragmentation on pteridophyte diversity in a tropical rain forest in Brazil. Plant Ecology 180: 87-104.

Page CN. 2002. Ecological strategies in fern evolution: a neopteridological averview. Review of Palaeobotany and Palynology 119: 1-33.

Perrie LR, Wilson RK, Shepherd LD, et al. 2014. Molecular phylogenetics and generic taxonomy of Blechnaceae ferns. Taxon 63: 745-758.

Ponce M, Mehltreter K, Sota E. 2002. Análisis biogeográfico de la diversidade pteridofítica em Argentina y Chile continental. Revista Chilena de Historia Natural 73: 703-717.

Prado J, Hirai RY. 2014. Biogeography of the brazilian atlantic forest: evidence from phylogenetic data sets and perspectives for fern and lycophytes studies. Fern Gazette 19: 241-257.

Prado J, Labiak PH 2009. Pteridófitas. In: Lopes MIMS, Kirizawa M, Melo MMRF (eds.) Patrimônio da Reserva Biológica do Alto da Serra de Paranapiacaba: a antiga Estação Biológica do Alto da Serra. São Paulo, Instituto de Botânica. p. 269-289.

Prado J, Sylvestre L. 2015. Lista de Espécies da Flora do Brasil. http:// floradobrasil.jbrj.gov.br/jabot/listaBrasil/ConsultaPublicaUC/ ResultadoDaConsultaNovaConsulta.do. 06 Feb. 2015.

Quevedo TC, Becker DFP, Schmitt JL. 2014. Estrutura comunitária e distribuição vertical de samambaias epifíticas em remanescente de Floresta Semidecídua no Sul do Brasil. Pesquisas, Botânica 65: 257-271.
Rambo B. 1950. A porta de Torres. A Bot Herb Rodrigues 2: 125- 136.

Rambo B. 1951. A imigração da selva higrófila no Rio Grande do Sul. Anais Botôtanicos do Herbário Barbosa Rodrigues 3: 55-91.

Rambo B. 1954. Historia da flora do litoral riograndense. Sellowia 6: 113-172.

Rambo B. 1956. A Fisionomia do Rio Grande do Sul. Porto Alegre, Selbach.

Ranal MA. 1995a. Estabelecimento de pteridófitas em mata mesófila semidecídua do Estado de São Paulo. 2. Natureza dos substratos. Revista Brasileira de Biologia 55: 583-594.

Ranal MA. 1995b. Estabelecimento de pteridófitas em mata mesófila semidecídua do Estado de São Paulo. 3. Fenologia e sobrevivência dos indivíduos. Revista Brasileira de Biologia 55: 777-787.

Ranal MA. 2003. Soil spore bank of ferns in a Gallery Forest of the ecological station of Panga, Uberlândia, MG, Brazil. American Fern Journal 93: 97-115.

Rocha LD, Droste A, Gehlen G, Schmitt JL. 2013. Leaf dimorphism of Microgramma squamulosa (Polypodiaceae): a qualitative and quantitative analysis focusing on adaptations to epiphytism. Revista de Biologia Tropical 61: 291-299.

Rothfels CJ, Sundue MA, Kuo LY, et al. 2012. A revised family-level classification for eupolypod II ferns Polypodiidae: Polypodiales. Taxon 61: 515-533.

Salino A, Almeida TE. 2008. Pteridófitas do Parque Estadual do Jacupiranga, SP, Brasil. Acta Botanica Brasilica 22: 83-991.

Santos ACC, Windisch PG. 2008. Análise da pteridoflora da Área de Proteção Ambiental do Morro da Borússia, Osório, RS. Pesquisas, Botânica 59: 237-252.

Santos MG, Sylvestre LS, Araújo DS. 2004. Análise florística das pteridófitas do Parque Nacional da Restinga de Jurubatiba, Rio de Janeiro, Brasil. Acta Botanica Brasilica 18: 271-280.

Sato T. 1982. Phenology and wintering capacity of sporophytes and gametophytes of ferns native to Northern Japan. Oecologia 55: 53-61.

Sato T, Sakai A. 1980. Freezing resistance of gametophytes of the temperate fern, Polystichum retroso-paleaceum. Canadian Journal of Botany 58: 1144-1148.

Sato T, Sakai A. 1981. Cold tolerance of gametophytes and sporophytes of some cool temperate ferns native to Hokkaido. Canadian Journal of Botany 59: 604-608.

Schmitt JL, Fleck R, Burmeister EL, Kieling-Rubio MA. 2006. Diversidade e formas biológicas de pteridófitas da Floresta Nacional de Canela, Rio Grande do Sul: contribuições para o plano de manejo. Pesquisas, Botânica 57: 275-288.

Schmitt JL, Goetz MNB. 2010. Species richness of fern and lycophyte in an urban park in the Rio dos Sinos, Southern Brazil. Brazilian Journal of Biology 70: 1161-1167.

Schmitt JL, Windisch PG. 2010. Biodiversity and spatial distribution of epiphytic ferns on Alsophila setosa Kaulf. (Cyatheaceae) caudices in Rio Grande do Sul, Brazil. Brazilian Journal Biology 70: 521-528.

Schmitt JL, Windisch PG. 2012. Caudex growth and phenology of Cyathea atrovirens (Langsd. \& Fisch.) Domin (Cyatheaceae) in secondary forest, southern Brazilian Journal of Biology 72: 397-405.

Schneider H, Schuettpelz E, Pryer KM, Cranfill R, Magallo S, Lupia R. 2004. Ferns diversified in the shadow of angiosperms. Nature 428: 553-557.

Schneider PH, Schmitt JL. 2011. Composition, community structure and vertical distribution of epiphytic ferns on Alsophila setosa Kaulf., in a Semideciduous Seasonal Forest, Morro Reuter, RS, Brazil. Acta Botanica Brasilica 25: 557-565.

Schwartsburd PB, Labiak PH. 2007. Pteridófitas do Parque Estadual de Vila Velha, Ponta Grossa, Paraná, Brasil. Hoehnea 34: 159-209.

Sehnem A. 1977. As filicíneas do sul do Brasil, sua distribuição geográfica, sua ecologia e suas rotas de migração. Pesquisas, Botânica 31: 1-108.

Senna RM, Waechter JL. 1997. Pteridófitas de uma floresta com araucária: formas biológicas e padrões de distribuição geográfica. Iheringia Série Botânica 48: 41-58.

Sharpe JM, Mehltreter K, Walker LR. 2010. Ecological Importance of Ferns. In: Mehltreter K, Walker LR, Sharpe JM. (eds.) Fern Ecology. New York, Cambridge University Press. p. 1-18.

Sheffields E. 1996. From pteridophyte spore to sporophyte in the natural eviroment. In: Camus JM, Gibby M , Johns RJ. (eds.) Pteridology in perspective, Kew, Royal Botanic Gardens. p. 541-550. 
Silva VL, Rocha LD, Coelho OGW, Schmitt JL. 2013. Heterogeneidade florística e edáfica de duas assembleias de samambaias na Floresta Atlântica do Estado do Rio Grande do Sul. Pesquisas, Botânica 64: 285-296.

Smith AR. 1972. Comparison of fern and flowering plant distributions with some evolutionary interpretations for ferns. Biotropica 4: 4-9.

Smith AR, Pryer KM, Schuettpelz E, Korall P, Schneider H, Wolf PG. 2008. Fern classification. In: Ranker TA, Haufler $\mathrm{CH}$. (eds.) Biology and evolution of ferns and Lycophytes. New York, Cambridge University Press. p. 417-467.

Sota ER. 1971. El epifitismo y las pteridófitas en Costa Rica (America Central). Nova Hedwigia 21: 401-465.

Sota ER. 1973. La distribución geográfica de las pteridofitas en el cono sur de América Meridional. Boletín de la Sociedad Argentina de Botánica 15: 23-34.

Souza FS, Salino A, Viana PL, Salimena FRG. 2012. Pteridófitas da Serra Negra, Minas Gerais, Brasil. Acta Botanica Brasilica 26: 378-390.

Sylvestre LS, Windisch PG. 2003. Diversity and distribution patterns of Aspleniaceae in Brazil. In: Chandra S, Srivastava M. (eds.) Pteridology in the New Millennium. Dordrecht, Kluwer Academic Publishers. p. 107-120.

Thiers B. 2015. Index Herbariorum: A global directory of public herbaria and associated staff. New York Botanical Garden's Virtual Herbarium. http://sweetgum.nybg.org/ih/. 06 Feb. 2015.

Tomazelli LJ, Dillenburg SR, Villwock JA. 2000. Late quaternary geological history of Rio Grande do Sul Coastal Plain, Southern Brazil. Revista Brasileira de Geociências 30: 474-476.

Tryon RM. 1942. A revision of the fern genus Doryopteris. Contribution of Gray Herbarium 143: 1-80.

Tryon RM. 1970. Development and evolution of fern floras of oceanic islands. Biotropica 2: 76-84.

Tryon RM 1972. Endemic areas and geographyc speciation in Tropical American Ferns. Biotropica 4: 121-131.

Tryon RM, Tryon AF. 1982. Ferns and allied plants with special reference to tropical America. New York, Springer.

Tuomisto H, Poulsen AD. 1996. Influence of edaphic specialization on pteridophyte distribution in neotropical rain forests. Journal of Biogeography 23: 283-293.

Tuomisto H, Ruokolainen K. 1993. Distribuition of Pteridophyta and Melastomataceae along an edaphic gradient in an Amazonian rain forest. Journal of Vegetation Science 4: 25-34.

Tuomisto H, Ruokolainen K, Yli-Halla M. 2003a. Dispersal, environment, and floristic variation of western Amazonian Forests. Science 299: 241-244.
Tuomisto H, Ruokolainen K, Aguilar M, Sarmiento A. 2003b. Floristic patterns along a 43-km long transect in Amazonian rain forest. Journal of Ecology 91: 743-756.

Tuomisto H, Zuquim G, Cárdenas G. 2014. Species richness and diversity along edaphic climatic gradientes in Amazonia. Ecography 37: 10341046.

Villwock JA, Tomazelli LJ. 2007. Planície costeira do Rio Grande do Sul: gênese e paisagem atual. In: Becker FG, Ramos RA, Moura LA. (eds.) Biodiversidade: Regiões da Lagoa do Casamento e dos Butiazais de Tapes, planície costeira do Rio Grande do Sul. Brasília, MMA/SBF. p. $20-33$.

Waechter JL. 1985. Aspectos ecológicos da vegetação de restinga no Rio Grande do Sul, Brasil. Comunicações do Museu de Ciencias PUCRS (Serie Botânica) 33: 49-68.

Waechter JL. 1990. Comunidades vegetais das restingas do Rio Grande do Sul. In: Anais do II Simpósio de Ecossistemas da Costa Sul e Sudeste Brasileira. Vol. 3. Águas de Lindóia. p. 228-248.

Waechter JL. 1998. Epiphytic orchids in eastern subtropical South America. Proceedings of the 15th World Orchid Conference, Rio de Janeiro, Brasil. Turriers, Naturalia Publications.

Waechter JL. 2002. Padrões geográficos na flora atual do Rio Grande do Sul. Ciência e Ambiente 24: 93-108.

Waechter JL, Jarenkow JA. 1998. Composição e estrutura do componente arbóreo nas matas turfosas do Taim, Rio Grande do Sul. Biotemas 11: 45-69.

Watkins Jr JE, Mack MC, Sinclair TR, Mulkey SS. 2007. Ecological and evolutionary consequences of desiccation tolerance in tropical fern gametophytes. New Phytologist 176: 708-717.

Williams S. 1938. Experimental morphology. In: Verdoom FR. (ed.) Manual of pteridology. The Hague, Martinus Nijhoff. p. 105-140.

Windisch PG. 1992. Pteridófitas da região Norte-Ocidental do Estado de São Paulo: guia para estudo e excursões. 2nd. edn. São José do Rio Preto, UNESP.

Windisch PG. 1996. Towards assaying biodiversity in Brazilian pteridophytes. In: Bicudo CEM, Menezes NA. (eds.) Biodiversity in Brazil: a first approach. São Paulo, CNPq. p. 109-117.

Windisch PG. 2002. Fern conservation in Brazil. Fern Gazette 16: 295-300.

Wolf PG, Schneider H, Ranker TA. 2001. Geographic distributions of homosporous ferns: does dispersal obscure evidence of vicariance? Journal of Biogeography 28: 263-270.

Zuloaga FO, Morrone O, Belgrano MJ. 2008. Catálogo de las plantas vasculares del Cono Sur (Argentina, sur de Brasil, Chile, Paraguay y Uruguay). Monographs in Systematic Botany, 107:1-778. 